\title{
Endogenous money and effective demand
}

\author{
Steve Keen \\ School of Economics, History and Politics, Kingston University, Kingston upon Thames, UK
}

Endogenous money is a core component of post-Keynesian economics, but it has not been fully integrated into its macroeconomics. To do so requires replacing the accounting truism that ex post expenditure equals ex post income with the endogenous money insight that ex post expenditure equals ex ante income plus the ex post turnover of new debt. This paper derives this result after exploring precedents to this concept in the work of Schumpeter, Minsky, Keynes and Pigou.

Keywords: endogenous money, effective demand, loanable funds, macroeconomics, monetary theory

JEL codes: $E 10, E 12$ E40, E44, E51

\section{INTRODUCTION}

The ideas which are here expressed so laboriously are extremely simple and should be obvious. The difficulty lies, not in the new ideas, but in escaping from the old ones, which ramify, for those brought up as most of us have been, into every corner of our minds. (Keynes 1936, p. xxiii)

The concept of endogenous money has been integral to post-Keynesian economics ever since the pioneering empirical work of Basil Moore (Moore 1979; 1983; 1988a; 1988b; 1995; 1997; 2001; 2006), and it is fundamental to Minsky's Financial Instability Hypothesis (Minsky 1963; 1972; 1975; 1977; 1980; 1982). The concept can be traced back to Schumpeter (Schumpeter 1934), and even further (though in not as explicit a form - see Newcomb 1886; Taussig 1911).

However, the ubiquity of the concept does not mean that its implications are fully understood, even by those who accept it is true, for the reason encapsulated in my opening quote from Keynes. Old ideas - even old ones from Keynes himself - can make it difficult to fully appreciate the consequences of a new idea. In this paper, I prove that a key concept in Keynes's General Theory (Keynes 1936) - the equality of income and expenditure and hence of savings and investment - must be modified for a model of capitalism with growth in which banks endogenously create money.

The starting point of the monetary macroeconomics of endogenous money is instead that effective demand is equal to income plus the turnover of new debt. This is entirely consistent with sectoral balances summing to zero, as I prove below.

\section{ANTECEDENTS}

The proposition that effective demand exceeds income is not a new one: it can be found in both Schumpeter and Minsky (and arguably in Keynes's writings after The General Theory, though not in as definitive a form - see Keynes 1937, p. 247). 
A difference between income and expenditure, with the gap filled by the endogenous creation of money, was a foundation of Schumpeter's vision of the entrepreneurial role in capitalism. Minsky's attempt to reconcile endogenous money and sectoral balances is the closest antecedent to the argument I make, but I will start in chronological order with Schumpeter's analysis.

\section{SCHUMPETER: ENDOGENOUS MONEY AND THE ENTREPRENEUR}

To Schumpeter, an entrepreneur was fundamentally someone with a good idea, but no money to put that idea into effect. Lacking money, he must either raise it or borrow it from a bank, and Schumpeter focused upon the latter route. ${ }^{1}$ The entrepreneur was therefore 'the typical debtor in capitalist society' (Schumpeter 1934, p. 102). When the bank advanced the entrepreneur a loan, this was not 'the transfer of existing purchasing power' but 'the creation of new purchasing power out of nothing ... which is added to the existing circulation' (Schumpeter 1934, p. 106, my emphasis).

Total demand in the economy was therefore the sum of demand from incomes earned by the sale of existing goods and services (which Schumpeter described as 'fully covered credit' in 'the circular flow') plus this debt-financed expenditure by entrepreneurs. Consequently total demand - which he describes as 'total credit' exceeds that from income alone:

From this it follows, therefore, that in real life total credit must be greater than it could be if there were only fully covered credit. The credit structure projects not only beyond the existing gold basis, but also beyond the existing commodity basis. (Schumpeter 1934, p. 101, emphasis added)

\section{MINSKY: SECTORAL BALANCE AND ENDOGENOUS MONEY}

Minsky confronted the issue of reconciling sectoral balances with effective demand exceeding income in his most famously named paper ('Can 'It" Happen Again?', Minsky 1963), and his first book-length treatment of the Financial Instability Hypothesis (John Maynard Keynes, Minsky 1975). In both cases he described his work as tentative heading the former 'A Sketch of a Model' and describing the latter as 'the bare bones of a model'. Since this issue remains contentious, with many post-Keynesian economists seeing an obvious double-counting error in the proposition that effective demand can exceed income (Berry et al. 2007; Keister and McAndrews 2009; Benes and Kumhof 2012), I cite this passage from Minsky (1963) in its entirety, to show that the argument that expenditure exceeds income has a long but neglected pedigree:

Within a closed economy, for any period

$$
(I-S)=(T-G)
$$

which can be written as:

$$
(S-I)+(T-G)=0
$$

1. Schumpeter acknowledged that many entrepreneurs have money (Schumpeter 1934, p. 73), and can also raise funds from share issues. But he focused on the extreme case of an entrepreneur with no money - which is the more difficult one - in order to clarify his argument. 
where $(S-I)$ is the gross surplus of the private sectors and $(T-G)$ is the gross surplus of the federal government. The surplus of each sector $\zeta_{j}(j=1 \ldots n)$ is defined as the difference between its gross cash receipts minus its spending on consumption and gross real investment, including inventory accumulations. We therefore have:

$$
\sum_{j=1}^{n} \xi_{j}=0
$$

Equation 3 is an ex post accounting identity. However, each $\zeta_{j}$ is the result of the observed investing and saving behavior of the various sectors, and can be interpreted as the result of market processes by which not necessarily consistent sectoral ex ante saving and investment plans are reconciled. If income is to grow, the financial markets, where the various plans to save and invest are reconciled, must generate an aggregate demand that, aside from brief intervals, is ever rising. For real aggregate demand to be increasing, given that commodity and factor prices do not fall readily in the absence of substantial excess supply, it is necessary that current spending plans, summed over all sectors, be greater than current received income and that some market technique exist by which aggregate spending in excess of aggregate anticipated income can be financed. It follows that over a period during which economic growth takes place, at least some sectors finance a part of their spending by emitting debt or selling assets.

For such planned deficits to succeed in raising income it is necessary that the market processes which enable these plans to be carried out do not result in offsetting reductions in the spending plans of other units. Even though the ex post result will be that some sectors have larger surpluses than anticipated, on the whole these larger surpluses must be a result of the rise in sectoral income rather than a reduction of spending below the amount planned. For this to take place, it is necessary for some of the spending to be financed either by portfolio changes which draw money from idle balances into active circulation (that is, by an increase in velocity) or by the creation of new money. (Minsky 1963; Minsky 1982, pp. 5-6, my emphasis)

Minsky thus appreciated that there were biconditional logical links between growing aggregate demand, demand exceeding income, and the endogenous creation of money, which at the same time had to be consistent with sectoral balances summing to zero as I prove later in this paper.

He returned to this theme in John Maynard Keynes (Minsky 1975, pp. 131-134) and attempted to construct a mathematical proof. In a section entitled 'The Economics of Budget Constraints', Minsky defined the budget constraint for consumption $(C)$ as wages $(W)$ plus a fraction $\alpha$ of income from the ownership of capital $(D$ - which included both distributed earning and interest payments on bonds) that was allocated to consumption spending. Ignoring debt-financed consumption or savings by workers for the sake of simplicity ('this assumption is not necessary - only convenient' (ibid., p. 131)), his equation for the consumption budget was:

$$
C=W+\alpha \cdot D
$$

Investment $(I)$ he defined as being equal to retained earnings $(\overparen{Q})$ times a leverage factor $(\lambda)$ :

$$
I=(1+\lambda) \cdot \widehat{Q}
$$


where $\lambda$ could range from negative during a debt-deflation to very large during a boom. The total budget constraint $(Y)$ was thus:

$$
Y=W+\alpha \cdot D+(1+\lambda) \cdot \widehat{Q} .
$$

Minsky reasoned that since $(1-\alpha) \cdot D$ of household income was not used for consumption, some fraction $(u)$ of it would be available to finance investment. It therefore followed that if the leveraged portion of investment exceeded this fraction of savings, then part of the investment had to be debt-financed:

If $\lambda \cdot \widehat{Q}>u \cdot(1-\alpha) \cdot D$, then some of investment will have to be financed in a manner other than by the intermediation of household savings. This excess $[\lambda \cdot \overparen{Q}-u \cdot(1-\alpha) \cdot D]$ of investment financing demanded over the supply available from intermediation of savings can be satisfied by some combination of an increase in the money supply and of a decrease in the money holdings in portfolios, i.e., by an increase in velocity. (Minsky 1975, p. 132, emphasis added)

Minsky then attempted to formalize the distinction between ex ante and ex post income, using a difference equation approach. He modelled planned or ex ante expenditure as depending on income levels in the previous period, so that

$$
\begin{aligned}
C_{t_{\text {exante }}} & =W_{t-1}+\alpha \cdot D_{t-1} \\
I_{t_{\text {exante }}} & =(1+\lambda) \cdot \widehat{Q}_{t-1} \\
Y_{t_{\text {exante }}} & =W_{t-1}+\alpha \cdot D_{t-1}+\widehat{Q}_{t-1}+\lambda \cdot \widehat{Q}_{t-1}
\end{aligned}
$$

Ex post income in period $t-1$ was

$$
Y_{t-1_{\text {expost }}}=W_{t-1}+D_{t-1}+\widehat{Q}_{t-1}^{2}
$$

For ex ante income in period $t$ to exceed ex post in period $t-1$, Minsky derived the condition that:

$$
\lambda \cdot \widehat{Q}_{t-1}>(1-\alpha) \cdot D_{t-1}
$$

He observed that, for income to grow, investment therefore had to exceed savings:

Thus for income to increase, the externally financed investment must exceed the savings of households. (Minsky 1975, p. 133)

For this to be possible, another source of finance had to exist: an increase in the money supply $(\Delta M)$ 'where $\Delta M_{t}$ can be either money creation or a change in velocity' (ibid., p. 133). Since a proportion $u$ of household savings was 'presumed to be made available for financing investment, we have that' (ibid., p. 133):

$$
\lambda \cdot \widehat{Q}_{t-1}=\Delta M_{t}+u \cdot(1-\alpha) \cdot D_{t-1} .
$$

Substituting that $\lambda \cdot \widehat{Q}_{t-1}>(1-\alpha) \cdot D_{t-1}$ from equation (1.6), Minsky concluded that for ex ante income in period $t$ to exceed ex post income in period $t-1-$ in other

2. I want to thank Marc Lavoie for pointing out errors in the equations in my draft paper seen by discussants. These emanated from the Kindle version I used for writing the draft paper, in which ex ante and ex post, $Y$ and $I$, and + and - were confused at various points. 


$$
\begin{gathered}
\Delta M_{t}>(1-\alpha) D_{t-1}-u(1-\alpha) D_{t-1} \\
\Delta M_{t}>(1-u)(1-\alpha) D_{t-1} \text { for } \\
Y_{t \text { ex ante }}>Y_{t-1 \text { ex post }}
\end{gathered}
$$

Figure 1 Minsky's equations from John Maynard Keynes (1975, p. 133)

words, for effective demand and income to grow over time - the creation of new money had to exceed the fraction of household income saved and not made available for investment (see Figure 1):

$$
\Delta M_{t}>(1-u) \cdot(1-\alpha) \cdot D_{t-1} .
$$

Minsky's principle thus transcends Keynes on both 'income equals expenditure' and 'savings equal investment', with Keynes's identities applying in the abstraction of equilibrium, but Minsky's applying in the (normally) growing economy in which we actually live. My analysis is thus consistent with Minsky, and formalizes the essential role of the endogenous creation of money by the banking sector in this analysis. But it still appears, to many post-Keynesians, to be contradicting Keynes himself.

\section{CONTRADICTING OR EXTENDING KEYNES?}

Minsky's insight that the endogenous creation of money by the banking sector is simultaneously an addition to demand that allows expenditure and income to grow over time supports Graziani's assertion that the banking sector must be treated as separate from the firm sector:

Since in a monetary economy money payments go necessarily through a third agent, the third agent being one that specialises in the activity of producing means of payment (in modern times a bank), banks and firms must be considered as two distinct kinds of agents. Firms are present in the market as sellers or buyers of commodities and make recourse to banks in order to perform their payments; banks on the other hand produce means of payment, and act as clearing houses among firms. In any model of a monetary economy, banks and firms cannot be aggregated into one single sector. (Graziani 1989, p. 4)

Keynes did not do this in The General Theory, arguing instead that 'technical monetary detail falls into the background':

... whilst it is found that money enters into the economic scheme in an essential and peculiar manner, technical monetary detail falls into the background. A monetary economy, we shall find, is essentially one in which changing views about the future are capable of influencing the quantity of employment and not merely its direction. But our method of analysing the economic behaviour of the present under the influence of changing ideas about the future is one which depends on the interaction of supply and demand, and is in this way linked up with 
our fundamental theory of value. We are thus led to a more general theory, which includes the classical theory with which we are familiar, as a special case. (Keynes 1936, pp. xxii-xxiii)

However, in Keynes's debates with critics in 1937, he began to appreciate the need to separate the banking sector from the firm sector when considering the 'finance demand for money'. In this next passage, Keynes also reached the conclusion derived by Minsky, above, that investment exceeds savings - though when speaking in terms of an individual entrepreneur:

I proceed to the third possible source of confusion, due to the fact (which may deserve more emphasis than I have given it previously) that an investment decision (Prof. Ohlin's investment ex-ante) may sometimes involve a temporary demand for money before it is carried out, quite distinct from the demand for active balances which will arise as a result of the investment activity whilst it is going on. This demand may arise in the following way. Planned investment - i.e. investment ex-ante - may have to secure its 'financial provision' before the investment takes place; that is to say, before the corresponding saving has taken place. It is, so to speak, as though a particular piece of saving had to be earmarked against a particular piece of investment before either has occurred, before it is known who is going to do the particular piece of saving, and by someone who is not going to do the saving himself. There has, therefore, to be a technique to bridge this gap between the time when the decision to invest is taken and the time when the correlative investment and saving actually occur.

This service may be provided either by the new issue market or by the banks; - which it is, makes no difference. Even if the entrepreneur avails himself of the financial provision which he has arranged beforehand pari passu with his actual expenditure on the investment, either by calling up instalments in respect of his new market-issue exactly when he wants them or by arranging overdraft facilities with his bank, it will still be true that the market's commitments will be in excess of actual saving to date and there is a limit to the extent of the commitments which the market will agree to enter into in advance. But if he accumulates a cash balance beforehand (which is more likely to occur if he is financing himself by a new market-issue than if he is depending on his bank), then an accumulation of unexecuted or incompletely executed investment-decisions may occasion for the time being an extra special demand for cash. To avoid confusion with Prof. Ohlin's sense of the word, let us call this advance provision of cash the 'finance' required by the current decisions to invest. Investment finance in this sense is, of course, only a special case of the finance required by any productive process; but since it is subject to special fluctuations of its own, I should (I now think) have done well to have emphasised it when I analysed the various sources of the demand for money. (Keynes 1937, pp. 246-247, italic and bold italic emphasis added)

Keynes's comments here arguably reach the same conclusion that Minsky later established, that investment exceeds savings in a growing economy, and the gap is filled by a rise in debt which also causes a rise in the stock of money.

\section{ENDOGENOUS MONEY AND EFFECTIVE DEMAND ${ }^{3}$}

We now proceed to generalize Minsky's closed economy results in a continuous time framework, prior to proving that expenditure exceeding income (and investment exceeding saving) at a point in time is consistent with recorded expenditure equalling recorded income over an accounting period.

3. The results in this section were derived jointly with Professor Matheus Grasselli. 
I start by defining income $\left(Y_{I}\right)$ as wages $(W)$ plus profits $(\Pi)$, where profits are either distributed to households $\left(\Pi_{D}\right)$ or retained by firms $\left(\Pi_{R}\right)$ :

$$
Y_{I}(t)=W(t)+\Pi(t)=W(t)+\Pi_{D}(t)+\Pi_{R}(t) .{ }^{4}
$$

Expenditure $\left(Y_{E}\right)$ is the sum of money spent purchasing either consumer goods $(C)$ or investment goods $(I)$ :

$$
Y_{E}=C+I \text {. }
$$

If income is to grow, then aggregate demand must rise over time, and, as Minsky put it, '[f]or real aggregate demand to be increasing ... it is necessary that current spending plans, summed over all sectors, be greater than current received income and that some market technique exist by which aggregate spending in excess of aggregate anticipated income can be financed' (Minsky 1963; Minsky 1982, p. 5, emphasis added). This generates a divergence between ex post expenditure and ex ante income, where that gap is financed by a rise in debt. ${ }^{5}$

Consumption by workers $\left(C_{W}\right)$ is therefore the sum of wages plus the turnover of new workers' debt used for consumption $\left(D_{W C}\right)$; and consumption by capitalists $\left(C_{\Pi}\right)$ is the sum of distributed profits plus the turnover of new capitalists' debt used to finance consumption ( $D_{\Pi C}-$ in all cases, the change in debt is debt to the banking sector). We assume that borrowed money is immediately spent, after which time it continues to circulate and therefore can be spent again at some rate $\delta$ - which I specify later:

$$
\begin{aligned}
& C_{W}=W+\delta \cdot \frac{d}{d t} D_{W C} \\
& C_{\Pi}=\Pi_{D}+\delta \cdot \frac{d}{d t} D_{\Pi C} .
\end{aligned}
$$

Investment is the sum of retained earnings plus the turnover of new debt of the firm sector $\left(D_{F I}\right)$ :

$$
I=\Pi_{R}+\delta \cdot \frac{d}{d t} D_{F I}
$$

Expenditure ex post minus income ex ante is thus equal to the turnover of new debt to the banking sector:

$$
Y_{E}-Y_{I}=\delta \cdot\left(\frac{d}{d t} D_{W C}+\frac{d}{d t} D_{\Pi C}+\frac{d}{d t} D_{F I}\right)
$$

As Minsky emphasized, for this to be possible there must either be an increase in the stock of money equivalent to the increase in debt, or an increase in the rate of circulation of money. The latter can emanate from changes in the behaviour of either lenders or borrowers: an increased willingness to invest can accelerate the rate of

4. To simplify notation, from now on I drop the explicit acknowledgement that all terms are functions of time.

5. This can also result from a change in the velocity of circulation of money, but I ignore this second-order process here. 
turnover of the existing stock of money. But for the former to occur, there must be a mechanism by which the physical stock of money is increased by a change in debt.

\section{MECHANISM OF ENDOGENOUS MONEY CREATION}

The creation of a loan by any entity to any other increases assets and liabilities identically and simultaneously, and this accounting truism misleads Neoclassical economists into believing that therefore the aggregate level of debt does not matter - only its distribution can have economic significance:

Ignoring the foreign component, or looking at the world as a whole, we see that the overall level of debt makes no difference to aggregate net worth - one person's liability is another person's asset. It follows that the level of debt matters only if the distribution of net worth matters, if highly indebted players face different constraints from players with low debt. (Krugman 2012b, p. 146)

However, as the Circuit School emphasizes, money is fundamentally a liability of the banking sector which other agents in the economy accept as complete payment in a transaction:

The only way to satisfy those three conditions is to have payments made by means of promises of a third agent, the typical third agent being nowadays a bank. When an agent makes a payment by means of a cheque, he satisfies his partner by the promise of the bank to pay the amount due. Once the payment is made, no debt and credit relationships are left between the two agents. But one of them is now a creditor of the bank, while the second is a debtor of the same bank. (Graziani 1989, p. 3)

Since the total stock of money in existence is the sum of the liabilities of the banking sector to the nonbank sectors of the economy, it follows that an increase in the assets and liabilities of the banking sector increases the money stock. In contrast, a loan from one nonbank entity to another does not change the stock of money in existence. Therefore changes in the aggregate liabilities of the banking sector do matter, because they directly change the supply of money - and, as I argue, they add to demand as well. Table 1 illustrates the difference between banking sector loans and non-banking sector loans by comparing the sale of a bond by the Firm Sector to the Household Sector which does not create money - with a loan by the Banking Sector to the Firm Sector, which does create money by creating a bank liability. ${ }^{6}$

Table 1 Parsimonious comparison of bond issue versus new loan

\begin{tabular}{|c|c|c|c|c|c|c|c|}
\hline \multirow[b]{3}{*}{ Flows } & \multicolumn{5}{|c|}{ Bank accounts } & \multicolumn{2}{|c|}{ Accounting sums } \\
\hline & \multicolumn{2}{|c|}{ Assets } & \multicolumn{2}{|c|}{ Liabilities } & \multirow{2}{*}{$\begin{array}{l}\text { Equity } \\
\text { Bank equity }\end{array}$} & \multirow[t]{2}{*}{ Row sum } & \multirow[t]{2}{*}{ Money creation } \\
\hline & Loans & Reserves & Firms & Households & & & \\
\hline Bond & & & -Bond & +Bond & & 0 & 0 \\
\hline Loan & +Loan & & -Loan & & & 0 & + Loan \\
\hline
\end{tabular}

6. In all these tables, I follow the accounting convention of showing a liability as negative, so that a liability is reduced by adding a positive amount to it. A transfer of $\$ X$ from account $\mathrm{A}$ to account $\mathrm{B}$ is thus shown as $+\$ X$ on account $\mathrm{A}$ and $-\$ X$ on account $\mathrm{B}$. 
While the actual process of lending can be very complicated, at a parsimonious level the mechanism of endogenous money creation is extremely simple: the simultaneous creation of an asset and a liability by the banking sector. I illustrate this with an example that also shows the link between money creation and an increase in demand - as well as the actual role of reserves as the means by which banks transfer liabilities.

There are five entities in the model: three banks - Buyer Bank, Seller Bank and the Central Bank; and two nonbank agents - Buyer and Seller. The account interactions between the three banks are shown in Table 2 to Table 4, along with the impact on the amount of bank liabilities (and hence the amount of money in circulation) at each step in the process.

Two sources of demand are modelled: a purchase from existing deposits ('Cash'); and a purchase financed by accessing debt (such as a line of credit or a credit card 'Card'). The Cash purchase uses funds generated from income; the Card purchase is obviously funded by an increase in debt.

The cash purchase reduces the Buyer's deposit by the amount 'Cash' (shown as a decrease in the Buyer Bank's liabilities in Table 2), thus reducing the Buyer Bank's assets and liabilities by the same amount. At this step in the process, the amount of money in circulation has fallen by Cash. However, the purchase increases the Seller's Deposit at the Seller Bank, and also increases the Seller Bank's Reserves by the same amount (shown on the first row of Table 3). The net effect, of course, is no change in the money supply.

The credit-financed purchase is shown in two stages: firstly the Buyer accesses his line of credit, increasing his Deposit and his Loans from the Buyer Bank by the same amount 'Card'. This creates new money by increasing the Buyer Bank's liabilities. Then the purchase is executed, which reduces the Buyer's Deposit by the same amount, and also reduces Buyer Bank's Reserves. The fall in Buyer Bank's liabilities reverses the money creation of the previous operation, so there is no net money creation at this point.

However, the transfer of the funds to the Seller's Deposit at Seller Bank increases the assets and liabilities of Seller Bank by the amount Card. There is therefore an

Table 2 Account operations at Buyer Bank

\begin{tabular}{|c|c|c|c|c|c|}
\hline \multicolumn{6}{|c|}{ Buyer Bank } \\
\hline & \multicolumn{2}{|c|}{ Assets } & \multirow{2}{*}{$\frac{\text { Liabilities }}{\text { Buyer deposit }}$} & \multirow{2}{*}{ Row sum } & \multirow{2}{*}{ Money change } \\
\hline & Loans & Reserves & & & \\
\hline $\begin{array}{l}\text { Buy with cash } \\
\text { Access credit } \\
\text { Buy with credit }\end{array}$ & + Card & $\begin{array}{l}\text {-Cash } \\
\text {-Card }\end{array}$ & $\begin{array}{l}\text { +Cash } \\
\text {-Card } \\
\text { Card }\end{array}$ & $\begin{array}{l}0 \\
0\end{array}$ & $\begin{array}{l}\text {-Cash } \\
+ \text { +Card } \\
\text {-Card }\end{array}$ \\
\hline
\end{tabular}

Table 3 Account operations at Seller Bank

\begin{tabular}{|c|c|c|c|c|}
\hline \multicolumn{5}{|c|}{ Seller Bank } \\
\hline & Assets & Liabilities & Row sum & Money creation \\
\hline & Reserves & Seller deposit & & \\
\hline Deposit cash revenue & + Cash & -Cash & 0 & + Cash \\
\hline Deposit card revenue & +Card & -Card & 0 & +Card \\
\hline
\end{tabular}


Table 4 Account operations at Central Bank

\begin{tabular}{llllll}
\hline & \multicolumn{4}{c}{ Central Bank } \\
\cline { 2 - 4 } & Assets & \multicolumn{2}{c}{ Liabilities } & Row sum & Reserve creation \\
\cline { 2 - 4 } & & $\begin{array}{c}\text { Buyer Bank } \\
\text { reserves }\end{array}$ & $\begin{array}{c}\text { Seller Bank } \\
\text { reserves }\end{array}$ & \\
\hline Buy with cash & & Cash & -Cash & 0 & 0 \\
Buy with card & Card & -Card & 0 & 0 \\
\hline
\end{tabular}

increase of the money supply by the amount Card. Since this was used to fund a purchase, the increase in the money supply is identical to the increase in transactions funded by the loan: the creation of new money is also an increase in demand.

The impacts of these transactions on the accounts of the Central Bank are shown in Table 4. Since both Cash and Card operations involve transfers between liability accounts at the Central Bank, no new Reserves are created by either operation; reserves are simply transferred from Buyer Bank to Seller Bank in both cases.

\section{ENDOGENOUS MONEY AND RESERVES}

Of course, if reserve requirement rules are in operation, then the Buyer Bank might need to acquire additional reserves to fulfil the requirements. Does this then limit private credit creation, as Neoclassical economists claim (Krugman 2012a)?

Two aspects of reality answer in the negative. First, as the European Central Bank stressed as recently as May 2012, reserve requirements are backward-looking: reserve requirements today are based on levels of loans and deposits typically one month earlier. Second, the Central Bank in practice must meet demands for Reserves from private banks, since if they did not, the system of interbank transfers would break down. My credit example illustrates this. $^{7}$

A Buyer with unused credit (in a negotiated line of credit, overdraft or credit card) has the right to access that unused credit at any time. If, at that time, the Buyer Bank was already on its Reserve limit (so that the transfer of Card would take it below its Reserve limit) and the Central Bank therefore refused to transfer reserves of Card from Buyer Bank to Seller Bank, then the Buyer's purchase would be voided - even though the Buyer had the necessary unused credit on his own contract with Buyer Bank. The impact of the Central Bank behaving this way would be catastrophic for Buyer Bank, and the interbank payments system in general.

This example puts flesh on New York Federal Reserve Vice-President Alan Holmes's discussion of the relationship between reserves and lending, when he attempted to block the push for the Fed to adopt Monetarist money growth targeting:

The idea of a regular injection of reserves - in some approaches at least - also suffers from a naive assumption that the banking system only expands loans after the System (or market

7. The same observation applies even for the Cash transfer, where it is conceivable that Buyer Bank might not have the Reserves needed to support the transfer of Cash from its Reserve account to Seller Bank's. In this situation, the Central Bank faces the non-choice of honouring the transfer anyway and allowing commerce to proceed smoothly, or of not allowing the transfer and causing the interbank payment system to collapse. 
factors) have put reserves in the banking system. In the real world, banks extend credit, creating deposits in the process, and look for the reserves later. The question then becomes one of whether and how the Federal Reserve will accommodate the demand for reserves. In the very short run, the Federal Reserve has little or no choice about accommodating that demand; over time, its influence can obviously be felt.

In any given statement week, the reserves required to be maintained by the banking system are predetermined by the level of deposits existing two weeks earlier... (Holmes 1969, p. 73, emphasis added $)^{8}$

Given the widespread ignorance of these issues within the economics profession itself, the ECB's very similar recent statement is worth quoting at length to show that the considerations which applied in Holmes's time continue to apply today:

The occurrence of significant excess central bank liquidity does not, in itself, necessarily imply an accelerated expansion of MFI credit to the private sector. If credit institutions were constrained in their capacity to lend by their holdings of central bank reserves, then the easing of this constraint would result mechanically in an increase in the supply of credit. The Eurosystem, however, as the monopoly supplier of central bank reserves in the euro area, always provides the banking system with the liquidity required to meet the aggregate reserve requirement. In fact, the ECB's reserve requirements are backward-looking, i.e. they depend on the stock of deposits (and other liabilities of credit institutions) subject to reserve requirements as it stood in the previous period, and thus after banks have extended the credit demanded by their customers...

In the case of normally functioning interbank markets, the Eurosystem always provides the central bank reserves needed on aggregate, which are then traded among banks and therefore redistributed within the banking system as necessary. The Eurosystem thus effectively accommodates the aggregate demand for central bank reserves at all times and seeks to influence financing conditions in the economy by steering short-term interest rates. (ECB 2012, pp. 21-22, emphases added)

If transfers between banks leave one bank in need of reserves, there are two sources: loans from another bank, or direct borrowing from the Central Bank. The Central Bank has an obvious motivation to want to provide such loans - the desire to keep the payments system functioning. In practice, private banks prefer to borrow reserves from each other when needed, and private banks with excess reserves banks face the motivation to lend of a higher return than from holding excess reserves themselves.

In my example, if Seller Bank began with no excess reserves before the transactions, it had excess reserves after them, because the transfer of funds from Buyer Bank increased Seller Bank's Reserves by precisely as much as Seller's Deposit account rose. Since the Reserve Requirement is a fraction of deposits (10 per cent of household deposits only in the USA - there is no reserve requirement for corporate deposits - see O'Brien 2007, p. 53), it now has more Reserves than it needs. Better to lend them at the interbank rate to Buyer Bank than to get no return (or a very low return) on the Reserves themselves. I model these two sources of required reserves in Tables 5-7.

On the Buyer Bank's accounts, both operations increase its assets, and give it matching liabilities, not to the nonbank public, but to the banking sector itself - therefore no new money is created. ${ }^{9}$

8. The lag is now 30 days - see O'Brien (2007, p. 53).

9. Money would be created if Buyer Bank then lent to the public (or government) from its liabilities to the banking sector. The fact that banks are currently unwilling to take this risk is 
282 Review of Keynesian Economics, Vol. 2 No. 3

Table 5 Reserve operations from Buyer Bank's perspective

\begin{tabular}{|c|c|c|c|c|c|c|}
\hline \multicolumn{7}{|c|}{ Buyer Bank } \\
\hline & Assets & \multicolumn{3}{|c|}{ Liabilities } & \multirow{3}{*}{$\begin{array}{l}\text { Row } \\
\text { sum }\end{array}$} & \multirow{3}{*}{$\begin{array}{l}\text { Money } \\
\text { change }\end{array}$} \\
\hline & \multirow[b]{2}{*}{ Loans Reserves } & \multicolumn{2}{|c|}{ Banking sector } & \multirow{2}{*}{$\begin{array}{c}\text { Nonbank } \\
\text { Buyer } \\
\text { deposit }\end{array}$} & & \\
\hline & & $\begin{array}{c}\text { Loan by } \\
\text { Central } \\
\text { Bank }\end{array}$ & $\begin{array}{c}\text { Loan by Seller } \\
\text { Bank }\end{array}$ & & & \\
\hline $\begin{array}{l}\text { Loan from Seller } \\
\text { Bank }\end{array}$ & Loan & & -Loan & & 0 & 0 \\
\hline $\begin{array}{l}\text { Loan from Central } \\
\text { Bank }\end{array}$ & New & $-\mathrm{New}$ & & & 0 & 0 \\
\hline
\end{tabular}

Table 6 Reserve operations from Seller Bank's perspective

\begin{tabular}{llccll}
\hline & \multicolumn{3}{c}{ Seller Bank } & & \\
& Assets & & Liabilities & Row sum & Money creation \\
\cline { 2 - 3 } & Reserves & $\begin{array}{c}\text { Loan by } \\
\text { Seller Bank }\end{array}$ & Seller deposit & & \\
\hline $\begin{array}{l}\text { Loan from } \\
\text { Seller Bank }\end{array}$ & -Loan & Loan & 0 & 0 \\
\hline
\end{tabular}

Table 7 Reserve operations from the Central Bank's perspective

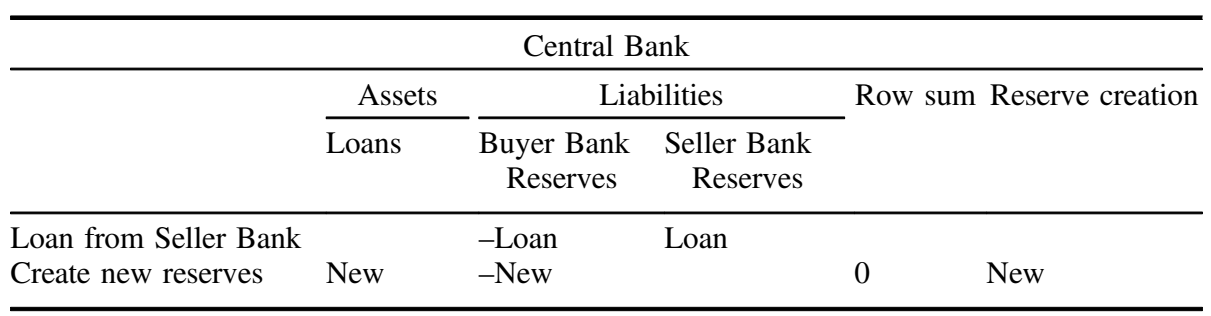

Seller Bank's liabilities are unchanged, but its Reserve assets fall and its incomeearning asset of loans to Buyer Bank increases.

The Central Bank records the loan by Seller Bank as a fall in Seller Bank's liabilities to it and a rise in Buyer Bank's, with no change in the level of reserves. Only the direct loan to Buyer Bank creates new reserves.

Reserves therefore do not constrain lending, and causation runs not from Reserves to private lending, but in the opposite direction: although the Central Bank can inject excess reserves, the level of required reserves is determined by the lending practices of the banking sector.

evident in the unprecedented level of excess reserves (currently of the order of US $\$ 1.5$ trillion versus the pre-crisis level of below US $\$ 2$ billion. See http://research.stlouisfed.org/fred2/series/ EXCRESNS. 
We now return to the topic of effective demand and the change in debt, firstly by deriving a value for $\delta$ in a manner that links the instantaneous formulae used in this paper with period analysis more customarily used in post-Keynesian economics.

\section{THE VELOCITY OF DEBT}

The starting point of endogenous money theory is that the rate of change of the money supply is identically equal to the rate of change of debt:

$$
\frac{d}{d t} M(t)=\frac{d}{d t} D(t)
$$

Consequently, in a pure credit economy, the amount of money in an economy is the initial amount (generated by fiat) plus the current level of debt:

$$
M(t)=\int \frac{d}{d t} D(t)=M(0)+D(t)
$$

The level of economic activity can be related to the level of money via the velocity of money $V$ - treated here not as a constant, as in Friedman's Monetarism, but merely as the ratio of expenditure to the money stock:

$$
V(t) \equiv \frac{Y(t)}{M(t)} .
$$

Therefore

$$
Y(t)=V(t) \cdot M(t)=V(t) \cdot \int \frac{d}{d t} D(t)
$$

Our unspecified constant $\delta$ in equations to is therefore the velocity of money.

If we consider some defined time period $t_{2}-t_{1}$, where $t_{2}$ and $t_{1}$ are both calendar dates and $t_{2}-t_{1}$ is a fraction of a year, then aggregate demand and income in a given period is the sum of aggregate demand and income at the beginning of that period, plus the change in debt over that fraction of a year, multiplied by the velocity of money:

$$
\begin{aligned}
Y\left(t_{2}-t_{1}\right) & =V\left(t_{1}\right) \cdot M\left(t_{1}\right)+\left(t_{2}-t_{1}\right) \cdot V(t) \cdot \int_{t_{1}}^{t_{2}} \frac{d}{d t} D(t) \\
& =Y\left(t_{1}\right)+\left(t_{2}-t_{1}\right) \cdot\left(V\left(t_{2}\right) \cdot D\left(t_{2}\right)-V\left(t_{1}\right) \cdot D\left(t_{1}\right)\right)
\end{aligned}
$$

If we consider a time period of one year, so that $\left(t_{2}-t_{1}\right)=1$ and $t_{1}=0$, and specify the change in debt over a year as $\Delta D(1)$, we have:

$$
Y(1)=Y(0)+v(1) \cdot \Delta D(1) .
$$

This enables us to operationalize Keynes's distinction between ex ante and ex post, while proving the consistency of this dynamic formula with the standard accounting 
identity that ex post expenditure equals ex post income. In words, these equations assert that ex post expenditure equals ex ante income, plus the velocity of money multiplied by the ex post change in debt.

Since the velocity of money comfortably exceeds unity (though it is highly variable and pro-cyclical), the numerical impact of the change in debt on aggregate demand is therefore larger than we have claimed in research. ${ }^{10}$

\section{INCLUDING SPECULATION IN EXPENDITURE}

As I detail in subsequent papers, ${ }^{11}$ by far the major use of credit creation today is to fund speculation in the FIRE sector, rather than purchases of goods and services. A truly monetary macroeconomics therefore must incorporate the FIRE sector in its analysis. The first step in doing this is to acknowledge that monetary expenditure is on both goods and services and assets $(A)$ :

$$
Y_{E}=C+I+A \text {. }
$$

Making a similarly convenient assumption to that made by Minsky with regard to workers' consumption, I focus solely on speculation by capitalists. Distributed earnings are now used for both consumption and speculation $\Pi_{S}$ :

$$
\Pi_{D}=\Pi_{C}+\Pi_{S}
$$

Asset purchases are funded both by distributed profits and new debt for speculation $D_{\Pi S}:$

$$
A=\Pi_{S}+V_{A} \cdot \frac{d}{d t} D_{\Pi S}^{12}
$$

The gap between expenditure and income now includes the change in debt used to finance speculation:

$$
Y_{E}=Y_{I}+V \cdot\left(\frac{d}{d t} D_{W C}+\frac{d}{d t} D_{\Pi C}+\frac{d}{d t} D_{F I}\right)+V_{A} \cdot \frac{d}{d t} D_{\Pi S} .
$$

\section{INCLUDING GOVERNMENT IN EXPENDITURE}

When the government sector is explicitly included, expenditure includes net government spending $(G-T)$, where the difference between $G$ and $T$ causes a change in government debt $D_{G}$. There are many additional nuances that complicate the analysis

10. This formula is derived in a rigorous manner in a related paper comparing loanable funds and endogenous money (Keen 2014).

11. This paper is part of a group of planned papers on endogenous money by Dirk Bezemer, Matheus Grasselli, Michael Hudson, and myself. Vicki Chick and Richard Werner make similar arguments in their joint paper.

12. Here, $V_{A}$ represents the velocity of money in the given asset market. 
(government generation of wages and profits; what the Central Bank does in response to a deficit), but the parsimonious outcome is as shown in equation (1.24):

$$
Y_{E}=Y_{I}+V \cdot\left(\frac{d}{d t} D_{W C}+\frac{d}{d t} D_{\Pi C}+\frac{d}{d t} D_{F I}+\frac{d}{d t} D_{G}\right)+V_{A} \cdot \frac{d}{d t} D_{\Pi S} .
$$

International trade and capital flows add substantial complications to both income and expenditure, but they do not alter the conclusion that effective demand is income plus the turnover of new debt. I will now address the apparent paradox that this is consistent with recorded income being identical to recorded expenditure.

\section{IDENTITY OF EX POST INCOME AND EXPENDITURE}

Absent new debt, expenditure is financed by incomes generated by the turnover of the existing stock of money, and the flow of expenditure can expand and contract as behaviour changes, while the volume of money in existence remains constant, if the rate of turnover of money changes. However, when an agent finances some expenditure by debt, there is a simultaneous injection of additional money via debt-financed expenditure into the turnover of the pre-existing stock of money and the expenditure it finances. After the debt is expended, that expenditure has become another agent's income (and part of the money stock which continues to circulate and finance expenditure), but at the point of the creation of new money, there is a discontinuity.

Figure 2 illustrates this with a hypothetical creation of $\$ 100$ million debt, which is then spent at time $d$ in a single day, when the level of income and expenditure prior to the debt-financed expenditure was $\$ 10$ billion per day (which itself reflected a rate of turnover of the existing stock of money). Prior to time $d$, the flow of expenditure was equivalent to the flow of income at the rate of $\$ 10$ billion per day. After time $d$, if the rate of turnover of the existing stock of money does not change, the flow of income and of expenditure will equal $\$ 10.1$ billion per day. The injection of the newly-created

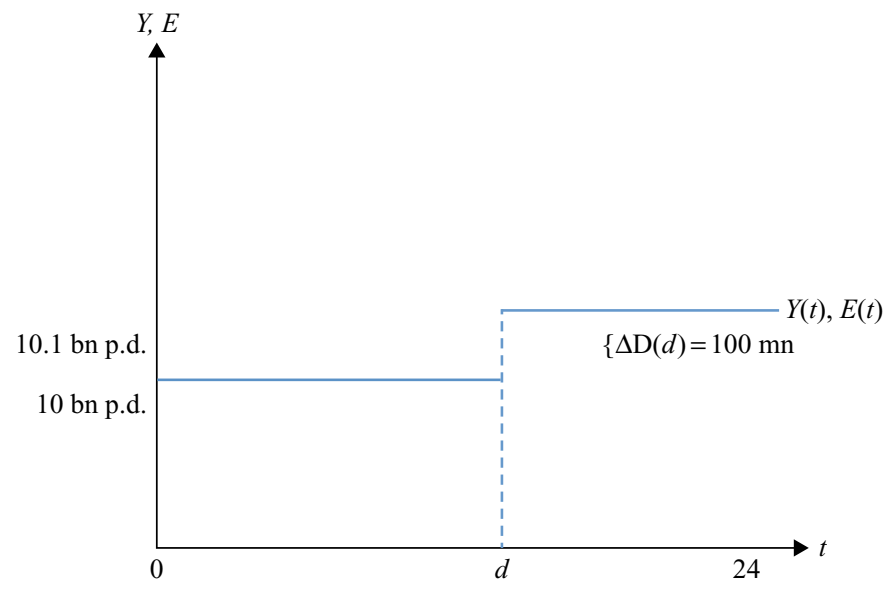

Figure 2 Debt-financed expenditure and a discontinuity in income 
money will cause a discontinuity at and only at time $d$. It will be greater or less than $\$ 100$ million if the rate of turnover of money does change, but there will still be a discontinuity.

The discontinuity means that there is a difference between income at time $t\left(Y_{I}(t)\right)$ income ex ante, prior to the debt injection - and income as it will be recorded by an accountant after the event for time $t\left(Y_{I}\left(t^{+}\right)\right)$- income ex post, after the debt injection. Expenditure at time $t\left(Y_{E}(t)\right)$ is therefore equal to income at time $t$, before the debt injection $\left(Y_{I}(t)\right)$, plus the debt injection $(\Delta D(t))$.

$$
\begin{aligned}
& Y(t<d)=\$ 10.0 \mathrm{bn} / \text { day } \\
& E(t<d)=\$ 10.0 \mathrm{bn} / \text { day } \\
& Y(d)=\$ 10.0 \mathrm{bn} / \text { day } \\
& E(d)=\$ 10.1 \mathrm{bn} / \text { day }=Y(d)+\Delta D(d) \\
& Y(t>d)=\$ 10.1 \mathrm{bn} / \text { day } \\
& E(t>d)=\$ 10.1 \mathrm{bn} / \text { day }
\end{aligned}
$$

The measurement of income and expenditure between any two points in time ( $t_{1}$ and $\left.t_{2}\right)$ corresponds to integration of the flows of income and expenditure over time. Since income and expenditure are identical to each other at all times except where there is a debt-financed addition to expenditure, and since debt is a discontinuous injection into the circular flow of existing income and expenditure, measurement will find that these two quantities are identical because of a property of integration that functions differing only at finitely many discontinuities must have identical integrals:

$$
\int_{t_{1}}^{t_{2}} Y_{E}(t) d t \equiv \int_{t_{1}}^{t_{2}} Y_{I}(t) d t .
$$

There is thus no conflict between the statements 'Recorded income equals recorded expenditure' and 'Expenditure equals income plus the change in debt'. But there is a very big difference between a macroeconomic theory which begins from the proposition that 'Aggregate demand equals aggregate income' and one that commences from 'Aggregate demand equals income plus the change in debt'. The former is only true in a Loanable Funds model of lending; the latter is true in the endogenous money world in which we actually live - as Schumpeter, Minsky, and (arguably) Keynes have asserted before us.

Nonetheless, since the expression 'Aggregate Demand' has been so linked to Aggregate Supply via the 'habitual modes of thought and expression' (Keynes 1936, p. xxiii) of the last 75 years, I propose resurrecting another of Keynes's terms that has fallen into disuse, 'Effective Demand', ${ }^{13}$ to state my starting point for macroeconomics that 'Effective Demand equals income plus the change in debt'.

In subsequent papers I explore the implications of this approach for a new, monetary macroeconomics. In this paper I will conclude with two brief empirical examples of the importance of this approach for macroeconomics and finance. More empirical analysis will be provided in subsequent papers.

13. I thank Nathan Tankus for this suggestion. 


\section{EMPIRICAL DATA ON DEBT AND AGGREGATE DEMAND}

Equation (1.23), which focused upon the role of change in the level of private debt in financing investment and consumption expenditure, can be summarized as asserting that private sector aggregate expenditure on goods and services will equal GDP plus the change in private sector debt. This in turn implies a relationship between change in debt and employment - amongst many other macroeconomic variables. The pure Neoclassical case, well captured in Bernanke's explanation of why Neoclassical economists ignored Fisher's debt-deflation theory of great depressions (Fisher 1933), is that any relationship between changes in the aggregate level of debt and macroeconomic variables will be slight:

Fisher's idea was less influential in academic circles, though, because of the counterargument that debt-deflation represented no more than a redistribution from one group (debtors) to another (creditors). Absent implausibly large differences in marginal spending propensities among the groups, it was suggested, pure redistributions should have no significant macro-economic effects... (Bernanke 2000, p. 24, emphasis added)

This position is somewhat attenuated by the 'Financial Accelerator' argument (Bernanke et al. 1996), but this asymmetric information argument relies upon credit rationing and a credit price channel, rather than the direct impact of changes in the aggregate level of debt. The Neoclassical a priori would therefore still be that changes in the total level of private debt should have no macroeconomic significance. This 'null hypothesis' is clearly rejected by the data: the correlation of the annual change in private debt (measured as a percentage of GDP) times velocity with the current unemployment rate over the 25 years from 1988 till 2013 is -0.92 (see Figure 3).

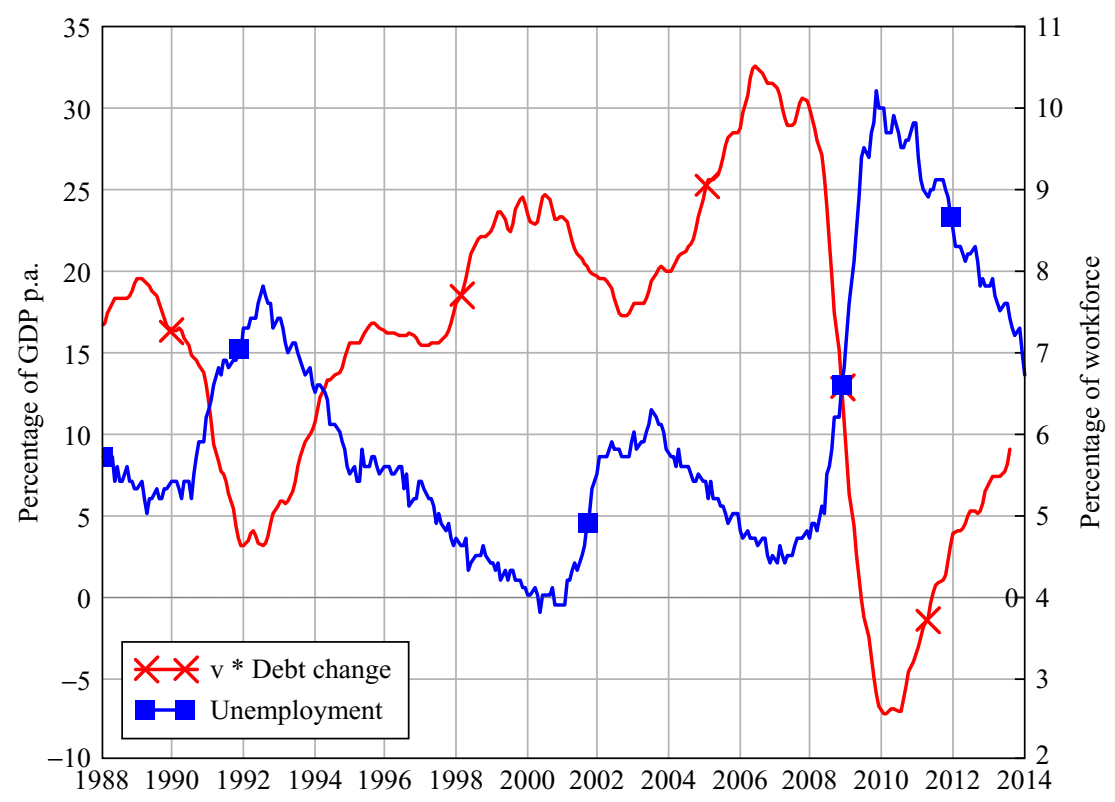

Figure 3 Correlation between change in US private debt and unemployment 
As an important aside, we have recently discovered that this empirical correlation, and the endogenous money causal mechanism behind it, was first proposed by Pigou in his Industrial Fluctuations (Pigou 1927). Pigou's analysis, in contrast to Keynes's in The General Theory, emphasized the importance of bank lending to the level of demand:

But their borrowings from banks are different. Business men are able to achieve extra borrowings of this type because the banks are ready, in response to offers of higher interest, to allow the ratio of their reserves to their liabilities to decrease. The ability to make these extra borrowings enables business men to enlarge the stream of floating capital available to them in good times more than they would have been able to do so in the absence of such ability ... In other words, modern practice in banking renders the supply of floating capital ... more elastic in response to given variations (whether warranted or not) in their outlook. (Pigou 1927, p. 121)

He asserted the correlation between changes in credit and the level of employment in his Table of Contents (see Figure 4).

He also provided a very similar graph of the relationship between changes in credit and the level of unemployment to my Figure 3 - see Figure 5. ${ }^{14}$

As noted in equation (1.20), the generalization of effective demand to include the change in debt also necessitates the generalization of supply to include net expenditure on asset markets. Debt-financed expenditure on assets will thus affect the asset price level, the turnover of assets, and the quantity (via new share issues and new dwelling construction). This leads to a relationship between the acceleration of debt and the rate of change of asset prices. Biggs, Mayer and Pick, who first developed this analysis,

\section{CHAPTER XIII}

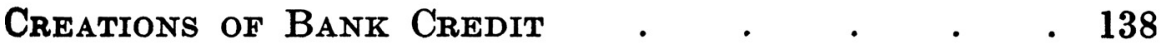

$\S 1$. The direct effects of creations of bank credit on the supply of new real capital are to be examined.

§ 2. A dicturn of Professor Cassel's is criticised,

$\S$ 3. And an objection of Professor Cannan's to the term "credit creation".

§§ 4-6. Subject to several qualifications, the addition made to bank deposits in any year is a rough index of the quantity of bank credit created for industrialists during that year.

$\S 7$. There is a close relation between fluctuations in the amount of credit creations and fluctuations in employment.

§ 8. The difference made to the supply of new capital in any year by the creation of bank credits is not equal to the real value of the credits created until two deductions have been made.

$\$ \S 9-11$. These deductions, both somewhat complex, are examined in detail.

Figure 4 Pigou's (1927) chapter 13 outline: 'There is a close relationship between fluctuations in the amount of credit creations and fluctuations in employment'

14. I thank Nathan Tankus for alerting us to this precedent. 


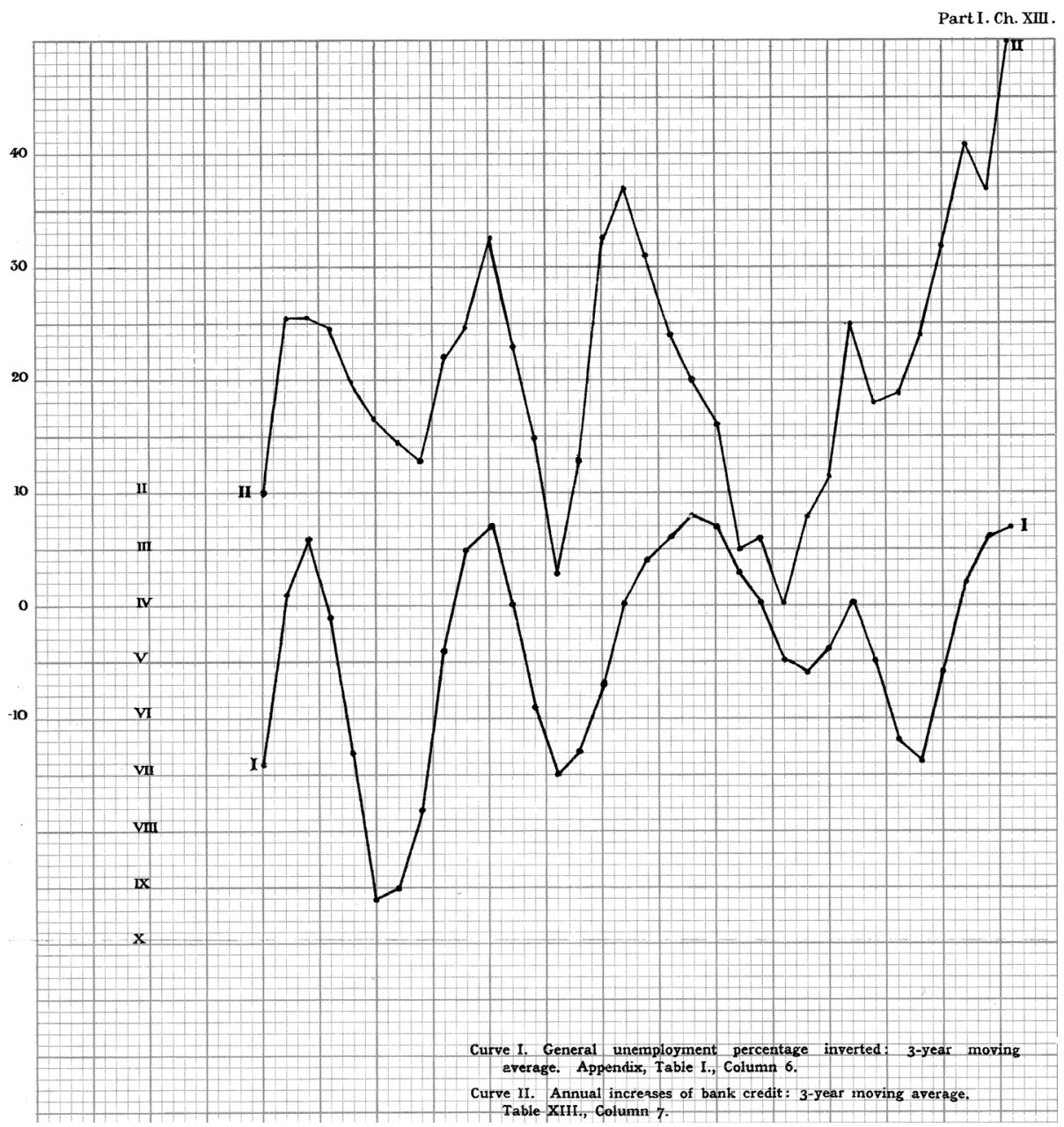

Figure 5 Change in bank debt and the unemployment rate from 1800 till 1920 (plate between pp. 132 and 133 of Pigou (1927))

defined the 'Credit Impulse' (Biggs and Mayer 2010; Biggs et al. 2010) as the acceleration of debt normalized by the level of GDP:

$$
C A(t)=\frac{V(t) \cdot \frac{d^{2}}{d t^{2}} D(t)}{G D P(t)} .
$$

I prefer to describe this as the 'Credit Accelerator' (since 'Impulse' implies a transient and exogenous phenomenon whereas acceleration is a permanent endogenous feature of a flow). I approximate this by the change in the change in debt over a year, divided by the level of GDP at the midpoint, to reduce the noisiness of the data. The correlation of the acceleration of mortgage debt with the change in the level of house prices since 1988 is 0.79 (see Figure 6). 


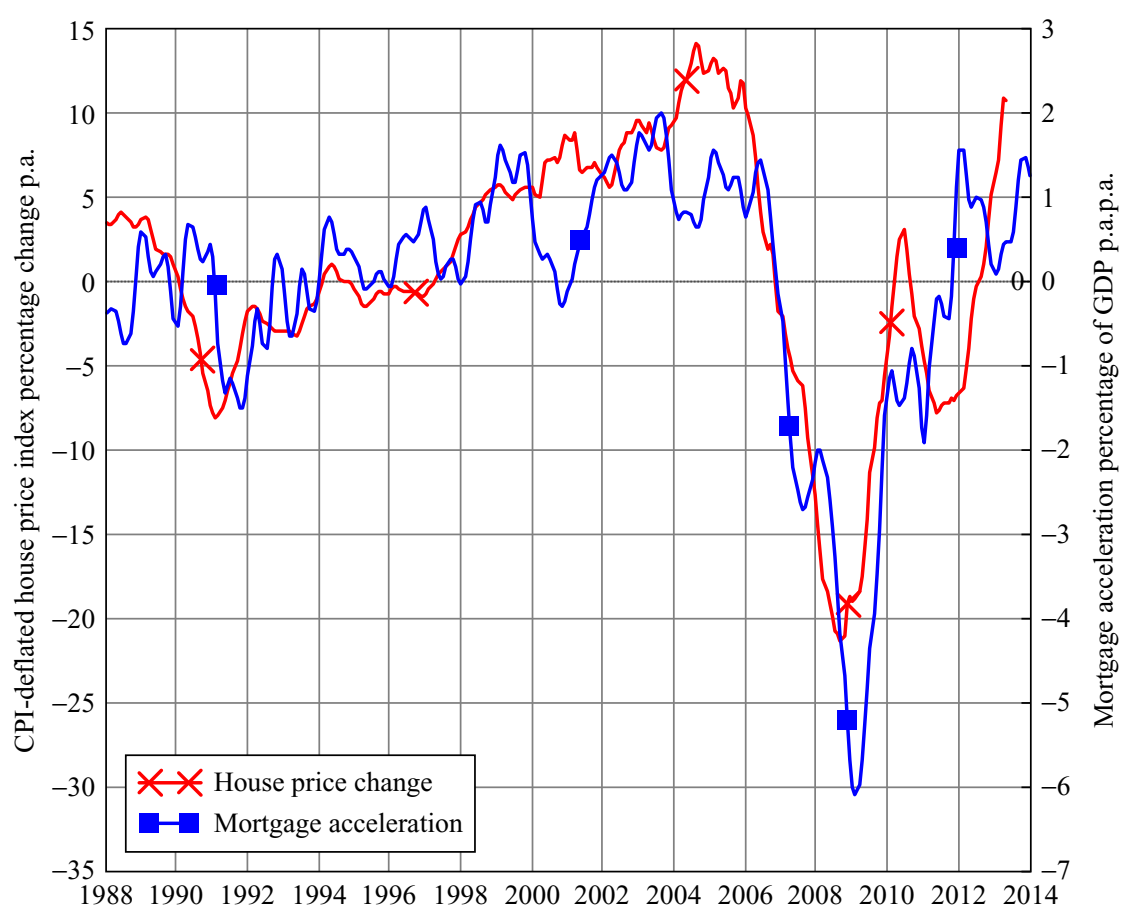

Figure 6 Correlation between acceleration of mortgage debt and change in CaseShiller house price index

\section{CONCLUSION}

The development of the theory of endogenous money was a major contribution by postKeynesian economists from Basil Moore onwards. To fully integrate it into macroeconomics, we have to move beyond the definition of aggregate demand in The General Theory - a work in which the role of banks in macroeconomics was conspicuously absent - to include the direct impact of changes in debt on effective demand, and beyond the definition of aggregate supply to incorporate the financial markets and the FIRE sector into macroeconomics. This will require overturning long-established conventions in post-Keynesian economics, but this is necessary if the full promise of the endogenous money revolution in macroeconomics is to be realized.

\section{REFERENCES}

Benes, J. and M. Kumhof (2012), 'The Chicago Plan Revisited'. IMF Working Paper. Washington, IMF.

Bernanke, B.S. (2000), Essays on the Great Depression. Princeton, NJ: Princeton University Press. Bernanke, B., M. Gertler and S. Gilchrist (1996), 'The Financial Accelerator and the Flight to Quality'. Review of Economics and Statistics, 78(1), 1-15.

Berry, S., R. Harrison, R. Thomas and I. de Weymarn (2007), 'Interpreting Movements in Broad Money'. Bank of England Quarterly Bulletin, Q3, 47(3), 376-388.

Biggs, M. and T. Mayer (2010), 'The Output Gap Conundrum'. Intereconomics/Review of European Economic Policy, 45(1), 11-16. 
Biggs, M., T. Mayer and A. Pick (2010), 'Credit and Economic Recovery: Demystifying Phoenix Miracles', SSRN eLibrary. Available at: http://ssrn.com/abstract=1595980.

ECB (2012), 'Monetary and Financial Developments'. Monthly Bulletin, May 2012. Brussels, European Central Bank.

Fisher, I. (1933), 'The Debt-Deflation Theory of Great Depressions'. Econometrica, 1(4), 337-357.

Graziani, A. (1989), 'The Theory of the Monetary Circuit', Thames Papers in Political Economy, Spring, 1-26.

Holmes, A.R. (1969), 'Operational Constraints on the Stabilization of Money Supply Growth'. In F.E. Morris (ed.), Controlling Monetary Aggregates. Nantucket Island: The Federal Reserve Bank of Boston, pp. 65-77.

Keen, Steve (2014), 'Modeling Financial Instability'. Available at: http://www.debtdeflation. com/blogs/2014/02/02/modeling-financial-instability/.

Keister, T. and J. McAndrews (2009), 'Why are Banks Holding So Many Excess Reserves?' New York, Federal Reserve Bank of New York.

Keynes, J.M. (1936), The General Theory of Employment, Interest and Money. London: Macmillan.

Keynes, J.M. (1937), 'Alternative Theories of the Rate of Interest'. Economic Journal, 47, 241-252.

Krugman, P. (2012a), 'Banking Mysticism, Continued: The Conscience of a Liberal'. Available at: http://krugman.blogs.nytimes.com/2012/03/30/banking-mysticism-continued/.

Krugman, P. (2012b), End this Depression Now! New York: W.W. Norton.

Minsky, H.P. (1963), Can 'It' Happen Again? Banking and Monetary Studies. D. Carson. Homewood: Richard D. Irwin, pp. 101-111.

Minsky, H.P. (1972), 'Financial Instability Revisited: The Economics of Disaster'. Reappraisal of the Federal Reserve Discount Mechanism. Washington, DC: Board of Governors of the Federal Reserve System, pp. 95-136.

Minsky, H.P. (1975), John Maynard Keynes. New York: Columbia University Press.

Minsky, H.P. (1977), 'The Financial Instability Hypothesis: An Interpretation of Keynes and an Alternative to "Standard" Theory'. Nebraska Journal of Economics and Business, 16(1), 5-16.

Minsky, H.P. (1980), 'Capitalist Financial Processes and the Instability of Capitalism'. Journal of Economic Issues, 14(2), 505-523.

Minsky, H.P. (1982), Can 'It' Happen Again? Essays on Instability and Finance. Armonk, NY: M.E. Sharpe.

Moore, B.J. (1979), 'The Endogenous Money Stock'. Journal of Post Keynesian Economics, 2(1), 49-70.

Moore, B.J. (1983), 'Unpacking the Post Keynesian Black Box: Bank Lending and the Money Supply'. Journal of Post Keynesian Economics, 5(4), 537-556.

Moore, B.J. (1988a), 'The Endogenous Money Supply', Journal of Post Keynesian Economics, 10(3), 372-385.

Moore, B.J. (1988b), Horizontalists and Verticalists: The Macroeconomics of Credit Money. Cambridge, UK: Cambridge University Press.

Moore, B.J. (1995), 'The Endogenous Money Supply'. In M. Musella and C. Panico (eds), The Money Supply in The Economic Process: A Post Keynesian Perspective. Aldershot, UK: Edward Elgar, pp. 459-472.

Moore, B.J. (1997), 'Reconciliation of the Supply and Demand for Endogenous Money'. Journal of Post Keynesian Economics, 19(3), 423-428.

Moore, B.J. (2001), 'Some Reflections on Endogenous Money'. In L.-P. Rochon and M. Vernengo (eds), Credit, Interest Rates and the Open Economy: Essays on Horizontalism. Cheltenham, UK: Edward Elgar, pp. 11-30.

Moore, B.J. (2006), Shaking the Invisible Hand: Complexity, Endogenous Money and Exogenous Interest Rates. Houndmills, UK and New York: Palgrave Macmillan.

Newcomb, S. (1886), Principles of Political Economy. New York, Harper \& Row.

O'Brien, Y.-Y.J.C. (2007), 'Reserve Requirement Systems in OECD Countries'. SSRN eLibrary. Available at: http://ssrn.com/paper=1038201.

Pigou, A.C. (1927), Industrial Fluctuations. London: Macmillan.

Schumpeter, J.A. (1934), The Theory of Economic Development: An Inquiry into Profits, Capital, Credit, Interest and the Business Cycle. Cambridge, MA: Harvard University Press.

Taussig, F.W. (1911), Principles of Economics. New York: Macmillan. 